\title{
Expression of p16, Rb, and p53 Proteins in Squamous Cell Carcinomas of the Anorectal Region Harboring Human Papillomavirus DNA
}

\author{
Danielle W. Lu, M.D., Samir K. El-Mofty, D.M.D., Ph.D., Hanlin L. Wang, M.D., Ph.D. \\ Lauren V. Ackerman Laboratory of Surgical Pathology, Department of Pathology and Immunology, \\ Washington University School of Medicine, St. Louis, Missouri
}

\begin{abstract}
Human papillomavirus (HPV) has been implicated as an etiologic agent for the development of squamous cell carcinoma of the anorectal region. It has been shown that the HPV E6 and E7 oncoproteins are able to inactivate the tumor suppressor functions of p53 and Rb. In cervical and head and neck cancers, HPV infection is also associated with an overexpression of p16, a cyclin-dependent kinase inhibitor. The expression of these cell cycle regulators in squamous cell carcinomas of the anorectal region has not been well studied. In the current study, 29 cases of squamous cell carcinoma of the anorectal region were immunohistochemically examined for the expression of $\mathrm{p} 16, \mathrm{Rb}$, and $\mathrm{p} 53$ proteins. Tumor cell DNA was also extracted from paraffin blocks and subjected to broad-spectrum HPV DNA testing and typing. The results show that the tumor cells exhibited a strong and diffuse nuclear stain (with some cytoplasmic positivity) for p16 in all 29 cases (100\%). The adjacent nonneoplastic squamous epithelium or colonic mucosa, in contrast, was completely negative. Loss of $\mathrm{Rb}$ nuclear staining in tumor cells was observed in 20 cases $(69 \%)$. The p53 protein was essentially undetectable, with only 6 cases containing $<10 \%$ positive cells. HPV DNA was detected in every case $(100 \%)$, with 25 cases $(86 \%)$ harboring Type 16 . In addition, almost identical results were obtained in 12 HPVpositive squamous cell carcinomas of the upper aerodigestive tract. This was in marked contrast to those of HPV-negative tumors, where positive p16 staining and loss of $\mathbf{R b}$ expression were seen in only $2 / 21(10 \%)$ and 1/21 (5\%) cases, respectively. These
\end{abstract}

\footnotetext{
Copyright (C) 2003 by The United States and Canadian Academy of Pathology, Inc.

VOL. 16, NO. 7, P. 692, 2003 Printed in the U.S.A

Date of acceptance: May 1, 2003.

Address reprint requests to: Hanlin L. Wang, M.D., Ph.D., Lauren V. Ackerman Laboratory of Surgical Pathology, Department of Pathology and Immunology, Campus Box 8118, Washington University School of Medicine, 660 South Euclid Avenue, St. Louis, MO 63110-1093; fax: 314-7472040; e-mail: hwang@path.wustl.edu.

DOI: 10.1097/01.MP.0000077417.08371.CE
}

observations indicate that overexpression of p16 and loss of Rb nuclear staining are commonly associated with high-risk HPV infection, which may serve as useful surrogate biomarkers for identifying squamous cell carcinomas harboring HPV DNA.

KEY WORDS: Anorectal, Human papillomavirus, p16, p53, Rb, Squamous cell carcinoma.

Mod Pathol 2003;16(7):692-699

Epidemiological and laboratory investigations have established a strong association of human papillomaviruses (HPV) with human cancers, particularly squamous cell carcinomas of the uterine cervix and anal canal, and some carcinomas of the upper aerodigestive tract (1-3). The carcinogenic effect of these "high-risk" HPVs, as defined by their documented association with invasive carcinomas (4), has been largely attributed to the products of two viral genes, E6 and E7, which are consistently expressed in cells infected by the viruses (5-7). It has been shown that the transforming activity of these two viral oncoproteins is mediated at least in part through inactivating the functions of two important cellular tumor suppressors p53 and Rb, which serve critical roles in regulating cell cycle control. The E6 oncoprotein interacts physically with p53 to promote its degradation via the ubiquitin-proteasome pathway $(8-10)$. On the other hand, the oncoprotein E7 forms a complex with Rb protein, leading to its functional inactivation as well as accelerated degradation $(11,12)$. These synergistic effects result in a deregulated cell cycle control and are thus believed to be critically important in HPV-induced carcinogenesis (1-3, 5, 6, 13-17). More recent studies have also demonstrated that the protein level of another cell cycle regulator, p16 (also known as p16 ${ }^{\text {INK4A }}$, MTS1, and CDKN2), is overexpressed in high-risk-HPV-related cervical cancers (18-22) and head and neck cancers (23). This is interesting because the expression of p16 is regulated by $\mathrm{Rb}$, presumably through a negative feedback mecha- 
nism $(24,25)$, and because p16 itself also functions as a tumor suppressor by inhibiting cyclindependent kinases 4 and 6 that phosphorylate $\mathrm{Rb}$ and thus decelerating the cell cycle progression (26).

Squamous cell carcinoma of the anal canal is uncommon, but its incidence has increased in recent years (27). Like in cervical cancers, high-risk types of HPV have been implicated in the pathogenesis in the majority of the cases (27-29). However, there are only a few studies that have examined the expression of p53 protein (30-33) and only one study that has examined the expression of $\mathrm{Rb}$ protein (32) in HPV-positive anal carcinomas, which have generated inconclusive results. The expression status of p16 protein in anal carcinomas has not yet been investigated. In the studies described in this report, the expression of $\mathrm{p} 16, \mathrm{Rb}$ and p53 proteins in 29 cases of squamous cell carcinoma of the anorectal region was examined immunohistochemically, and the HPV status in these tumors was analyzed by sensitive PCR-based assays. Our data demonstrate that high-risk HPV infection correlates with overexpression of p16 and loss of Rb nuclear staining.

\section{MATERIALS AND METHODS}

\section{Clinical Specimens}

Twenty-nine cases of squamous cell carcinoma of the anorectal region were retrieved from the 1989-2002 surgical pathology archives at Washington University Medical Center, including 25 biopsies and 4 resections. Clinical data were reviewed to ensure that they were indeed anorectal primaries. Formalin-fixed, paraffin-embedded tissue blocks were available from each case. Hematoxylin and eosin (H\&E)-stained slides were reexamined to confirm the original diagnosis. In addition, $12 \mathrm{HPV}-$ positive and $21 \mathrm{HPV}$-negative squamous cell carcinomas from the upper aerodigestive tract, which have been characterized previously (34), were included for comparison.

\section{DNA Extraction and HPV DNA Detection and Typing}

Tumor tissue from paraffin blocks was dissected using a sterile blade, followed by deparaffinization twice in a $1.5-\mathrm{mL}$ tube with $1 \mathrm{~mL}$ xylene and washing twice with $1 \mathrm{~mL}$ of $100 \%$ ethanol. The tissue samples were digested with proteinase $\mathrm{K}(1 \mathrm{mg} / \mathrm{mL})$ in a volume of $0.1-0.3 \mathrm{~mL}$ at $56^{\circ} \mathrm{C}$ overnight. The proteinase $\mathrm{K}$ was then inactivated by boiling for 10 minutes, and $2 \mu \mathrm{L}$ of DNA aliquot was directly used for polymerase chain reaction (PCR). In these experiments, broad-spectrum HPV DNA amplifica- tion was performed employing the short PCR fragment (SPF10) primer set provided by Delft Diagnostic Laboratory (the Netherlands), exactly following the manufacturer's instructions. Specifically, the SPF10 primers amplify a 65-bp DNA fragment from the L1 region of the HPV genome (35, $36)$, with the primer sequences described previously (35). The PCR products were subjected to electrophoresis on a $4 \%$ low melting agarose gel, and the 65 -bp band was visualized by ethidium bromide staining. In every experiment, an HPVpositive and an HPV-negative control were included. All cases were analyzed at least twice using different DNA concentrations. In addition, PCR amplification of the $\beta$-globin gene was performed using the primers described by Saiki et al. (37) to ensure adequate DNA quality.

Samples positive for HPV DNA were further genotyped using the INNO-LiPA (line probe assay) HPV genotyping research prototype kit provided by Delft Diagnostic Laboratory. This assay detects 25 different HPV genotypes (high-risk HPVs: 16, 18, 31, $33,35,39,45,51,52,53,56,58,59,66,68,70$; and low-risk HPVs: $6,11,34,40,42,43,44,54,74$ ) simultaneously in a single analysis (36). Briefly,

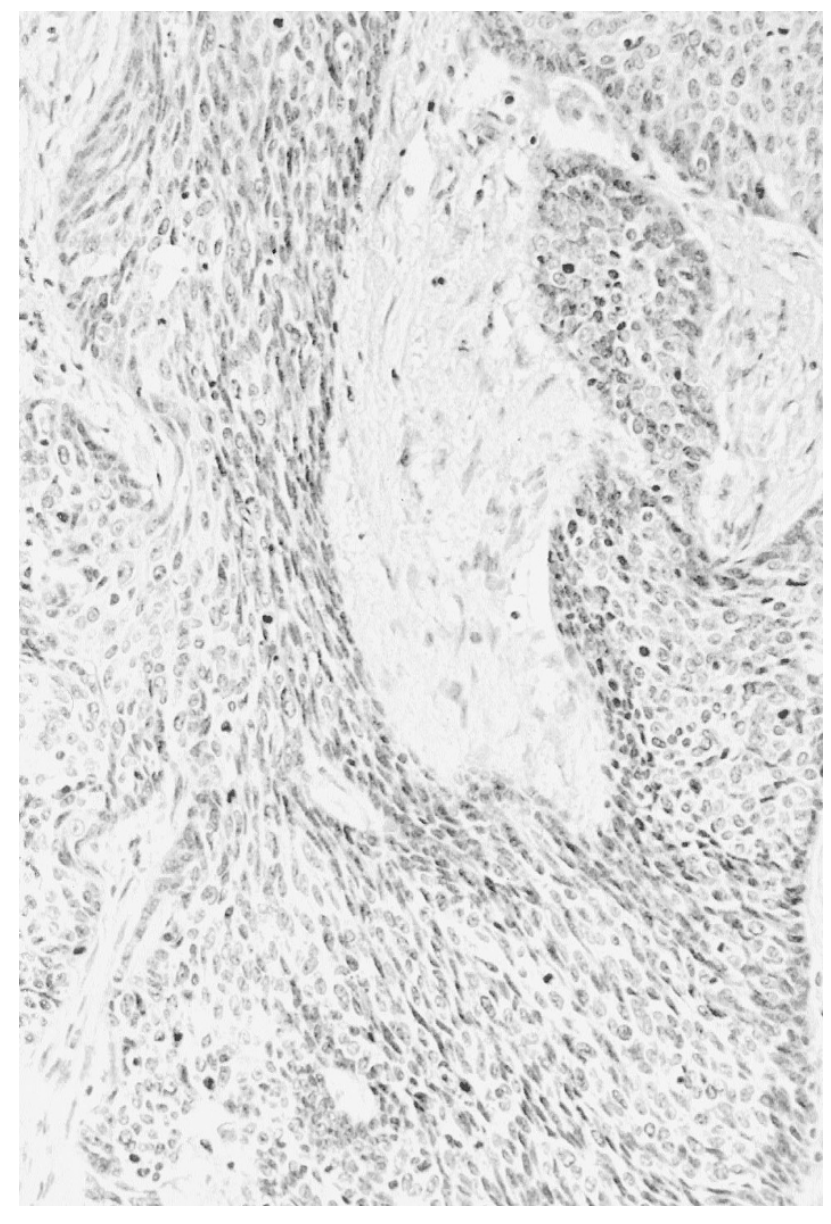

FIGURE 1. Squamous cell carcinoma of the anorectal region showing basaloid features without overt keratinization (H\&E; original magnification, $200 \times$ ). 
biotin-labeled PCR products were reverse hybridized to specific probes on the LiPA strips under highly stringent conditions. Alkaline phosphataselabeled streptavidin was then added, and the hybridized complex was visualized by incubation with chromogens nitroblue tetrazolium and 5-bromo-4chloro-3-indolyl phosphate. The results of hybrid- ization were analyzed by comparing to the standard grid provided by the manufacturer.

\section{Immunohistochemistry}

Immunohistochemical studies were performed on $4-\mu \mathrm{m}$ tissue sections using commercially avail-
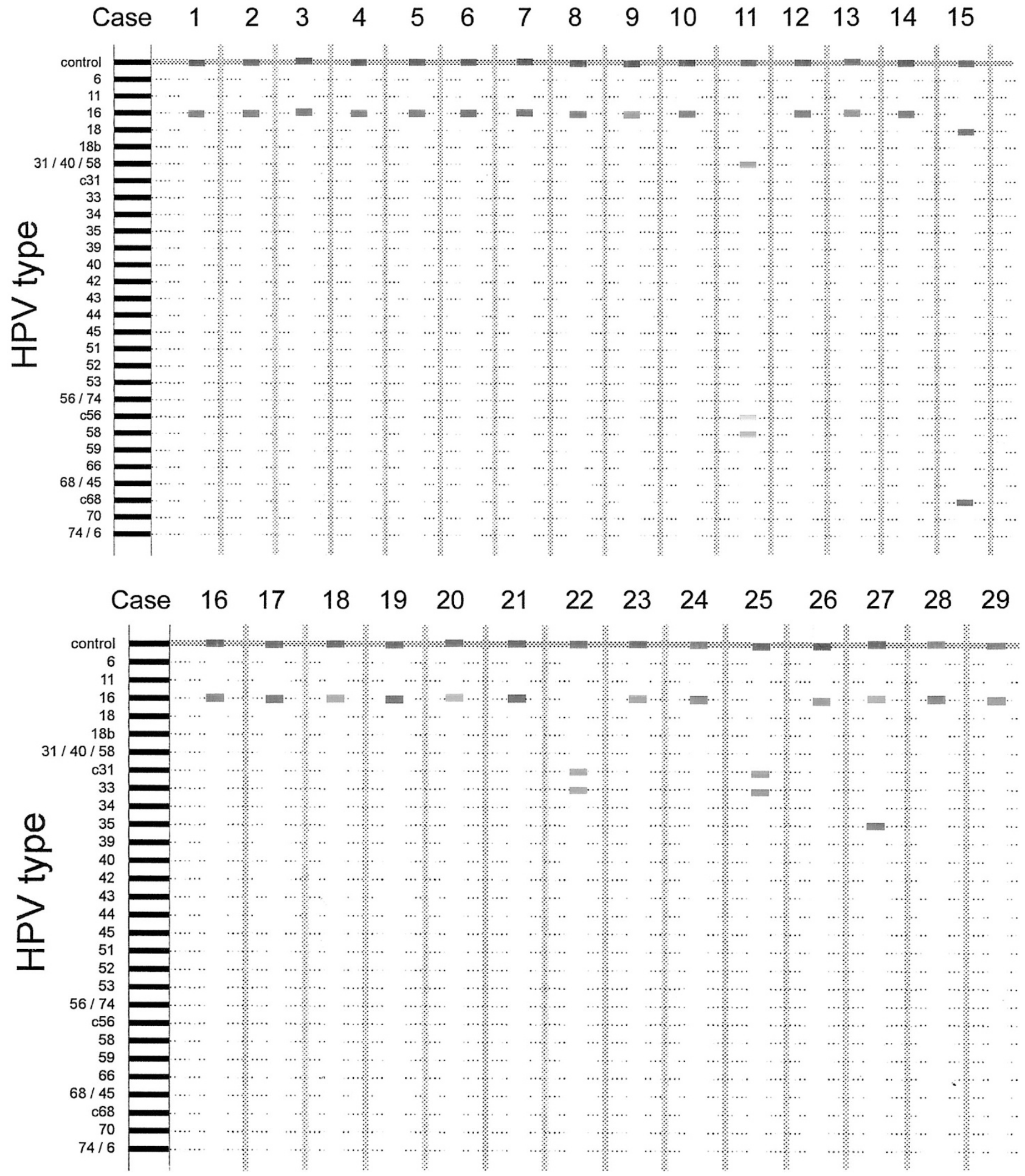

FIGURE 2. Identification of HPV genotypes in anorectal squamous cell carcinomas using line probe assay (LiPA). Note that HPV 58 (Case 11) was reactive with three probes, 31/40/58, c56, and 58; HPV 18 (Case 15), with two probes, 18 and c68; and HPV 33 (Cases 22 and 25 ), with two probes, c31 and 33. Two HPV types (16 and 35) were detected in Case 27. These experiments have been repeated once, and those results were identical. 


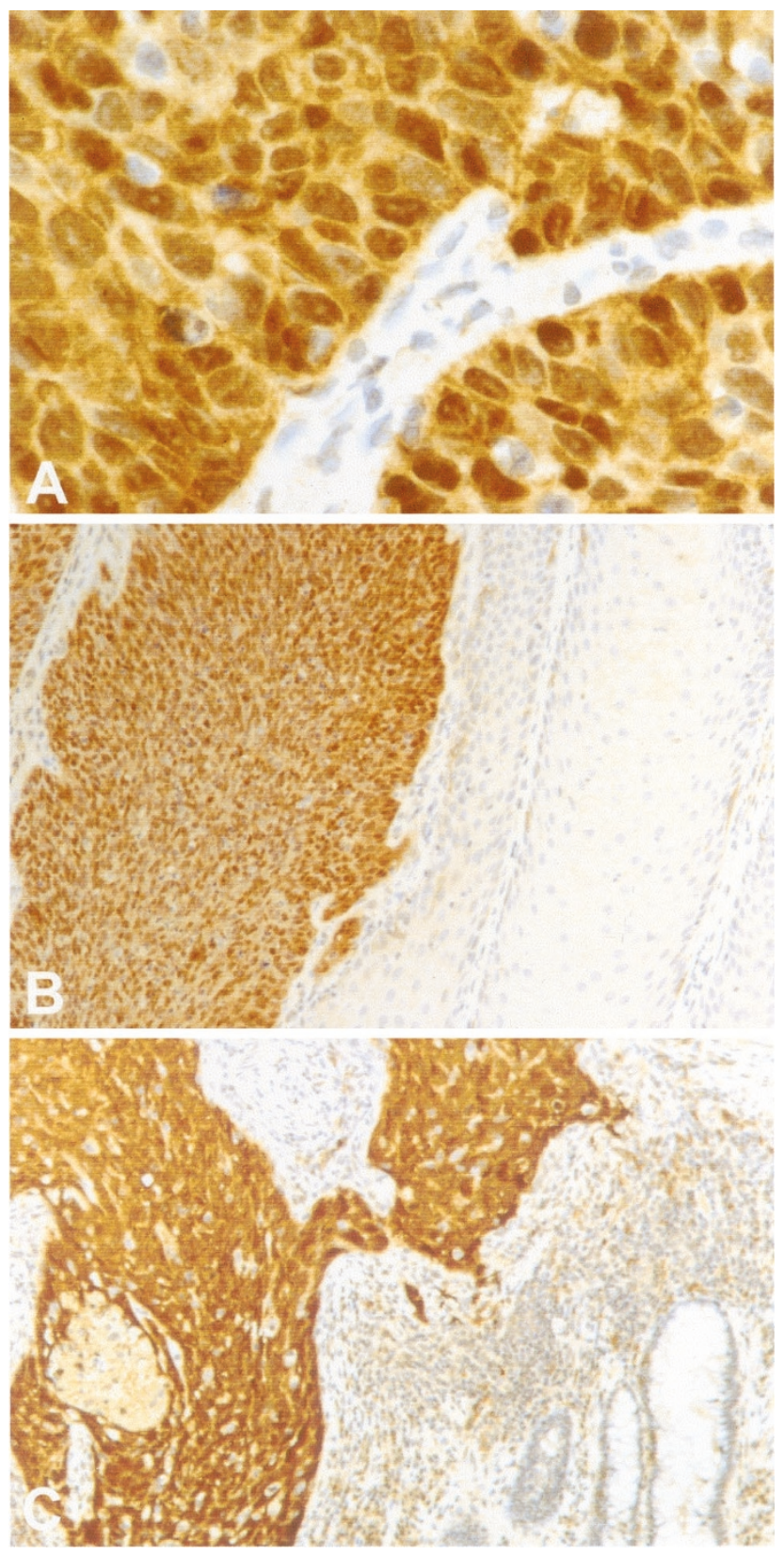

FIGURE 3. Immunohistochemical staining for p16 showing a strong and diffuse immunoreactivity in anorectal squamous cell carcinomas, with a predominantly nuclear staining and some cytoplasmic positivity (A; original magnification, $400 \times$ ). The adjacent nonneoplastic squamous epithelium (B; right) and colonic mucosa (C; right lower) were essentially negative for nuclear staining (original magnification, $100 \times)$.

able monoclonal antibodies. These included mouse IgG2b against p16 (clone 6H12) obtained from Novocastra Laboratories Ltd. (United Kingdom) and mouse IgG1 against $\mathrm{Rb}$ (clone IF8) and mouse IgG2a against p53 (clone DO-1) obtained from Santa Cruz Biotechnology, Inc. (Santa Cruz, CA). Immunohistochemical staining was conducted employing the DAKO LSAB2 horseradish peroxidase system (DAKO Corp., Carpinteria, CA), following the manufacturer's instructions with slight modifi- cations (38). Briefly, deparaffinized tissue sections were first treated with $3 \% \mathrm{H}_{2} \mathrm{O}_{2}$ for 15 minutes to inhibit endogenous peroxidase followed by antigen retrieval using microwave heating in $10 \mathrm{~mm}$ citrate buffer (pH6.0) for 10 minutes. After incubation with blocking serum for 20 minutes, sections were incubated with primary antibodies described above for 1 hour at room temperature, with an antibody dilution of 1:40 for anti-p16 and 1:100 for anti-Rb and anti-p53. After further incubation with biotinylated link antibody and peroxidase-labeled streptavidin, the staining was developed by reaction with 3,3'diaminobenzidine substrate-chromogen solution, followed by counterstaining with hematoxylin. In each experiment, a negative control in which the primary antibodies were replaced by preimmune mouse IgG and a positive control were included.

Nuclear staining was considered positive for p16, $\mathrm{Rb}$, and $\mathrm{p} 53$. A tumor was recorded positive if $>10 \%$ of the tumor cells showed immunoreactivity. The staining characteristics were compared with adjacent nonneoplastic squamous epithelium and/or colonic mucosa.

\section{RESULTS}

\section{Clinicopathologic Features of Anorectal Squamous Cell Carcinomas}

The patients with anorectal squamous cell carcinomas included in this study ranged in age from 38 to 85 years (mean age, $61.5 \mathrm{y}$ ), with a male to female ratio of 1:2.2. Clinical presentation was either an anal mass (16 cases) or a rectal mass (13 cases). Twenty-five patients were managed with radiation and chemotherapy after the diagnosis was established by biopsies, without further surgical intervention. The remaining 4 patients underwent surgical resections, with all tumors being Stage I. Histologically, the majority of the cases (83\%) exhibited basaloid features without overt keratinization (Fig. 1). Only 5 cases showed focal keratinization.

\section{HPV DNA Detection and Typing}

Using the SPF10 PCR primer set, HPV DNA was amplified in all 29 anorectal squamous cell carcinomas $(100 \%)$, irrespective of the presence or absence of keratinization in tumor cells (data not shown). Further HPV genotyping employing INNOLiPA demonstrated that all the cases were associated with high-risk types, with HPV16 being the most prevalent one detected in 25 cases (86\%). The other HPV types included 18 ( 1 case), 33 (2 cases), and 58 ( 1 case). One case also showed coinfection with two viral types (16 and 35). These results are presented in Figure 2. 


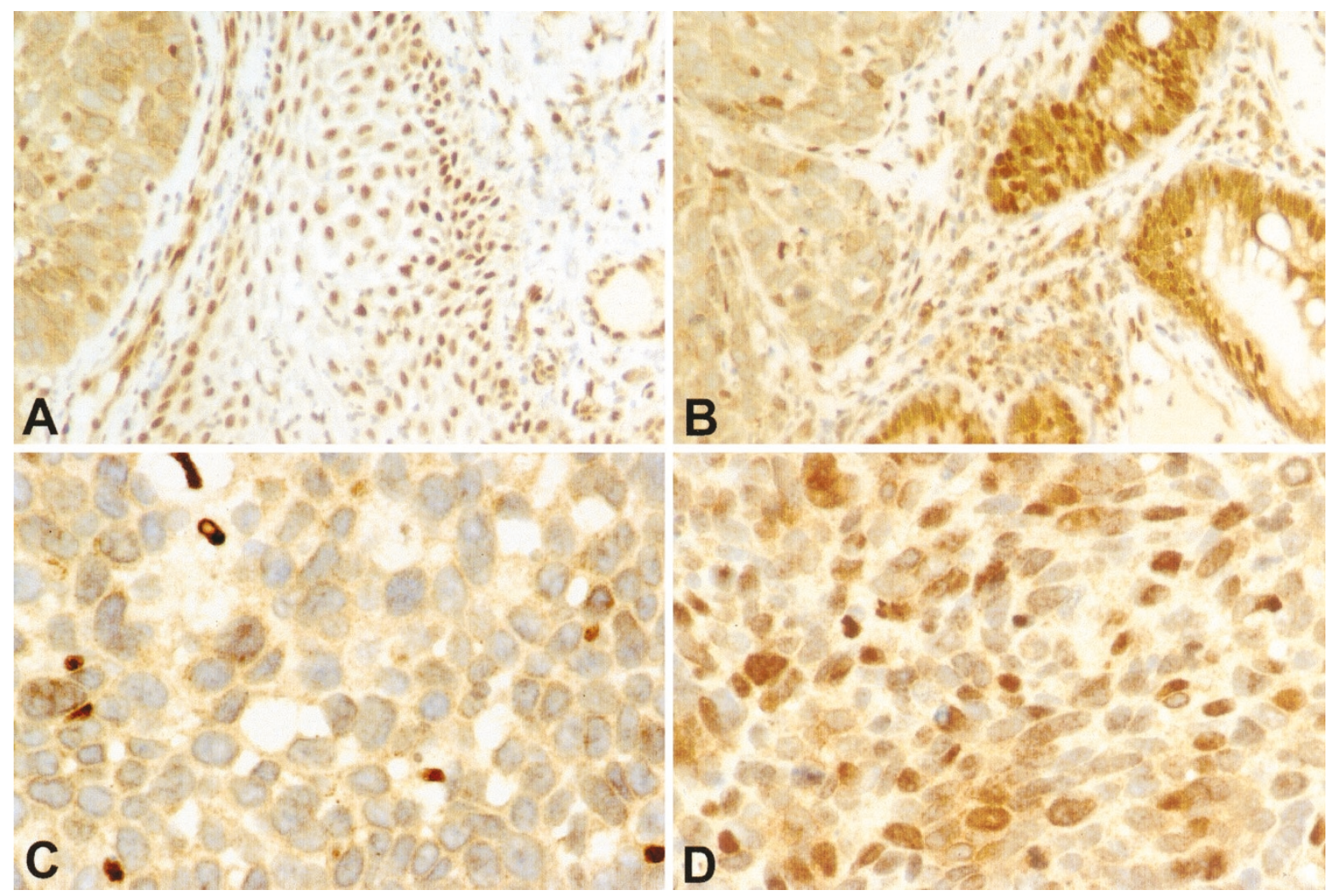

FIGURE 4. Immunostaining for Rb showing a uniform nuclear positivity in nonneoplastic squamous epithelium (A) and colonic mucosa (B) adjacent to anorectal squamous cell carcinoma (left; original magnification, $200 \times$ ). Higher power view highlighting the loss of Rb nuclear staining observed in two thirds of the anorectal squamous cell carcinomas (C; original magnification, $400 \times)$. Note that intratumoral inflammatory cells were positive, which served as "built-in" controls. The nuclear immunoreactivity for Rb retained in the remaining cases (D; original magnification, $400 \times)$.

\section{Immunohistochemical Findings}

Strong and diffuse nuclear staining (with some cytoplasmic positivity) for p16 was observed in all 29 cases $(100 \%)$ of anorectal squamous cell carcinoma (Fig. 3). The adjacent nonneoplastic squamous epithelium or colonic mucosa present in some of the cases was either completely nonimmunoreactive or exhibited weak membranous or focal cytoplasmic positivity. No nuclear staining was evident in nonneoplastic epithelial cells in any of the cases.

Nuclear positivity for Rb was universally present in nonneoplastic cells (Fig. 4). However, nuclear staining for $\mathrm{Rb}$ was observed in only 9 cases of anorectal squamous cell carcinomas. Twenty cases (69\%) showed a loss of $\mathrm{Rb}$ nuclear staining in tumor cells with only weak cytoplasmic immunoreactivity detected (Fig. 4). The presence or absence of keratinization in tumor cells did not appear to influence the $\mathrm{Rb}$ immunostaining characteristics. The p53 protein was essentially undetectable in both tumor and nonneoplastic cells in 23 cases. The remaining 6 cases $(21 \%)$ showed positive staining for p53 in scattered tumor cells. Because the positive tumor cells accounted for $<10 \%$ of the population in these cases, they were also considered to be negative (Fig. $5)$.

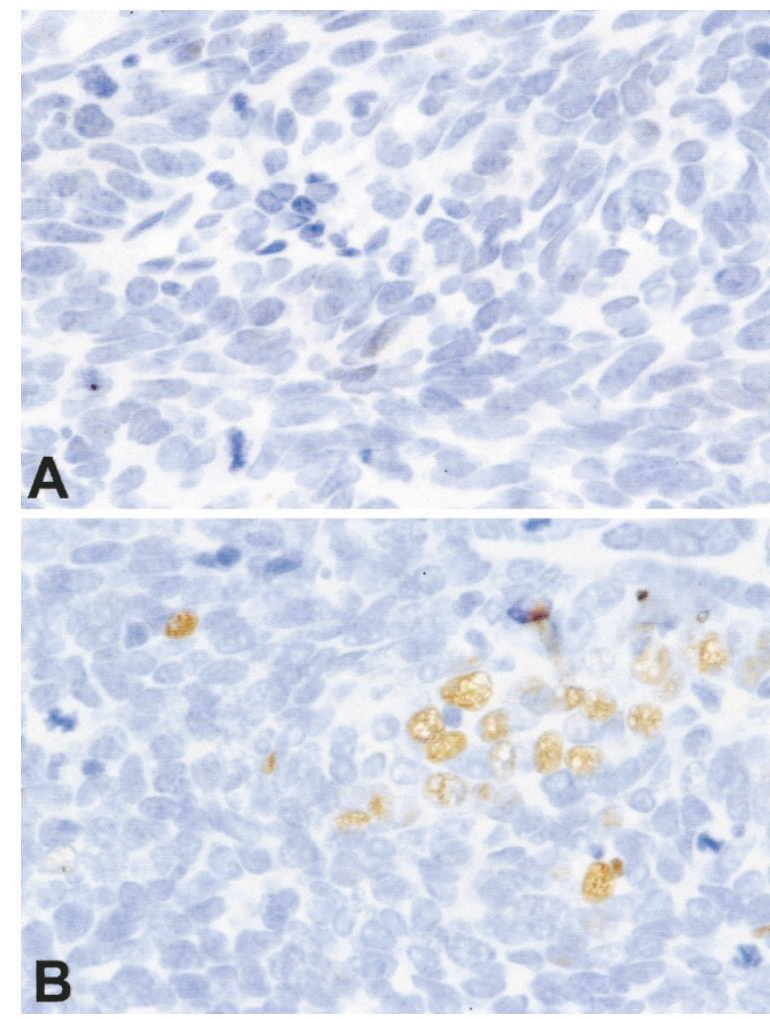

FIGURE 5. Immunostaining for p53 showing a completely negative reactivity in the majority of the anorectal squamous cell carcinomas (A). Only six cases exhibited focal positivity seen in $<10 \%$ of the tumor cells (B; original magnification, $400 \times$ ). 
Because all anorectal squamous cell carcinomas included in this study harbored HPV DNA, control cases from upper aerodigestive tract were similarly studied immunohistochemically for comparison. These included 12 cases of HPV-positive and 21 cases of HPV-negative squamous cell carcinomas. The results of these studies and a comparison with the findings from anorectal cancers are presented in Table 1.

\section{DISCUSSION}

The etiopathogenetic importance of high-risk HPV infection in several human cancers has been well established by numerous studies (1-3). In keeping with this notion, we demonstrate that all 29 cases of squamous cell carcinoma of the anorectal region studied in this report are associated with high-risk HPV types, particularly Type 16. In addition, our results show aberrant expression patterns of several important cell cycle regulators in these HPV-related anorectal cancers, further supporting the hypothesis that disruption of the normal cell cycle regulation by the E6 and E7 viral oncoproteins serves critical roles in mediating HPV-induced carcinogenesis $(1-3,15)$.

One of the major functions of the viral protein E6 is to inactivate p53, a well-studied cellular tumor suppressor that, under the normal physiologic conditions, promotes cell cycle arrest at the late G1 phase and prevents the propagation of genetically damaged cells (39). It is interesting to note, however, that the mechanism by which HPV E6 oncoprotein deregulates p53 is via a direct protein-protein interaction to induce degradation of the p53 protein (8-10). This is different than that occurring in many other types of human cancers, where mutations of the $p 53$ gene are the targeting events (39). In this regard, an early study by Crook et al. (40) demonstrated no $p 53$ gene mutations in a limited number of HPV-positive anal squamous cell carcinomas, suggesting that p53 mutations and HPV infection may be mutually exclusive. However, the results of a few immunohistochemical studies, an indirect but useful method to detect $p 53$ mutations (41), are somewhat conflicting. The reported fre- quency of coexistence of p53 protein overexpression and HPV infection in anal squamous cell carcinomas in these studies varied from $10.3 \%$ to $64.3 \%$ (30-33). Although our data presented in this report are broadly in agreement with these published findings in that 6 of 29 cases $(21 \%)$ showed p53 nuclear overexpression in some of the tumor cells, it is important to emphasize that the positivity was focal and only seen in a minority of the tumor cells. It is thus reasonable to speculate that mutations of the $p 53$ gene may not serve a major role in HPVinduced carcinogenesis in the anorectal region. This notion is in line with the fact that HPV E6 oncoprotein facilitates p53 protein degradation (8-10).

Another important tumor suppressor that is also targeted by HPV is $\mathrm{Rb}$, a nuclear phosphoprotein that plays a key role in regulating the cell cycle (26). The HPV E7 oncoprotein preferentially interacts with the hypophosphorylated $\mathrm{Rb}$, the active form, resulting in a functional inactivation as well as an acceleration of protein degradation $(11,12)$. Similar to what has been reported for the $p 53$ gene, no gross rearrangement or loss of the $R b$ locus was observed in squamous cell carcinomas of the anus in one early study by Southern blotting analysis (40). In the current study, we demonstrate that loss of $\mathrm{Rb}$ nuclear staining by immunohistochemistry is frequently associated with HPV infection in anorectal squamous cell carcinomas, which occurred in $69 \%$ of the cases. Although these findings differ somewhat from those reported by Tanum and Holm (32), who showed a heterogeneous Rb nuclear staining in $95 \%$ of the cases they studied, our results support the concept that $\mathrm{Rb}$ protein is deregulated through two different mechanisms in HPV-related anorectal cancers. That is, in some of the tumors, Rb is inactivated by the HPV E7 oncoprotein at the functional level, and thus the nuclear $\mathrm{Rb}$ protein remains detectable immunohistochemically. In other tumors, however, $\mathrm{Rb}$ deregulation is achieved through accelerated protein degradation, as evidenced by a negative nuclear staining. This concept is further indirectly supported by the results of p16 immunostaining, as discussed below.

The p16 protein is also a key cell cycle regulator that functions as a tumor suppressor and is a com-

TABLE 1. Comparison of p16, Rb, and p53 Expression between Squamous Cell Carcinomas of the Anorectal Region and the Upper Aerodigestive Tract with and without HPV Infection

\begin{tabular}{|c|c|c|c|}
\hline \multirow{3}{*}{ Staining Characteristics } & \multicolumn{3}{|c|}{ No. of Cases (\%) } \\
\hline & \multirow{2}{*}{$\frac{\text { Anorectal Region }}{\text { HPV-Positive }}$} & \multicolumn{2}{|c|}{ Upper Aerodigestive Tract } \\
\hline & & HPV-Positive & HPV-Negative \\
\hline Positive p16 nuclear staining & $29(100)$ & $12(100)$ & $2(10)$ \\
\hline Loss of $\mathrm{Rb}$ nuclear staining & $20(69)$ & $7(58)$ & $1(5)$ \\
\hline Positive p53 nuclear staining & 0 & 0 & $6(29)$ \\
\hline Total cases & 29 & 12 & 21 \\
\hline
\end{tabular}


mon target of inactivation in human cancers (42). It has been recently reported, however, that in HPVrelated cervical and head and neck cancers, p16 protein is overexpressed as detected by immunohistochemistry (18-23). These paradoxical findings are thought to result from a negative feedback control mechanism secondary to Rb deregulation (22, $24,25)$. It has been well established that there exists an inverse relationship between the expression of p16 and the presence of functional Rb in many cell systems and that $\mathrm{Rb}$ represses the transcription of the $p 16$ gene $(24,25)$. However, once the inhibitory effect of $\mathrm{Rb}$ is abolished by either functional inactivation or protein degradation, as seen in HPVinfected cells, the transcriptional activity and the protein expression level of p16 are expected to increase. Similar to those reported in cervical and head and neck cancers (18-23), the results presented in this report show that p16 is overexpressed in $100 \%$ of the cases of anorectal squamous cell carcinomas that harbor HPV DNA. The p16 immunoreactivity seen in tumor cells is strong, highly reproducible, and detected in nearly every tumor cell in all cases. These observations further support the hypothesis that in HPV-related anorectal squamous cell carcinomas, the tumor suppressor function of the $\mathrm{Rb}$ protein is nullified even if it remains detectable immunohistochemically in a subset of the tumors.

A number of studies have attempted to investigate whether HPV infection bears any prognostic significance in squamous cell carcinomas of the cervix (43-48), penis (49), lung (50), and head and neck region $(51,52)$. Although the accumulated data are inconclusive and controversial, it seems to be useful to separate tumors that are HPV related from those that are not because different etiopathogenetic pathways are involved. In general, molecular detection of HPV DNA in tumor cells requires sophisticated laboratory facilities and experienced personnel and is costly. It therefore may not be feasible to be implemented into daily practice in many surgical pathology laboratories. From this perspective, the expression patterns of cell cycle regulators, as detected by immunohistochemical staining, may serve as good surrogate markers (20, 53). This view is substantiated by our findings showing a strong correlation between p16 overexpression and high-risk type HPV infection in anorectal squamous cell carcinomas. Because all the cases we studied harbor HPV DNA, we have also included HPV-positive and HPV-negative tumors from the upper aerodigestive tract for comparison. The results of these studies further indicate that $\mathrm{p} 16$ overexpression is fairly specific for HPV-related tumors. Our data also show that loss of Rb nuclear staining is another relatively specific marker for high-risk type HPV infection, which is seen in about two thirds of HPV-related tumors but only rarely occurs in HPV-negative cases. Furthermore, immunostaining for p53 does not appear to be useful in the distinction between HPV-positive and HPVnegative cancers.

Acknowledgments: The authors thank Ms. Prosperidad Amargo for her excellent technical assistance.

\section{REFERENCES}

1. zur Hausen H. Papillomavirus infections-a major cause of human cancers. Biochim Biophys Acta 1996;1288:F55-78.

2. Munger $\mathrm{K}$. The role of human papillomaviruses in human cancers. Front Biosci 2002;7:d641-9.

3. Sisk EA, Robertson ES. Clinical implications of human papillomavirus infection. Front Biosci 2002;7:e77-84.

4. Lorincz AT, Reid R, Jenson AB, Greenberg MD, Lancaster W, Kurman RJ. Human papillomavirus infection of the cervix: relative risk associations of 15 common anogenital types. Obstet Gynecol 1992;79:328-37.

5. Watanabe S, Kanda T, Yoshiike K. Human papillomavirus type 16 transformation of primary human embryonic fibroblasts requires expression of open reading frames E6 and E7. J Virol 1989;63:965-9.

6. zur Hausen H. Human papillomaviruses in the pathogenesis of anogenital cancer. Virology 1991;184:9-13.

7. Jeon S, Lambert PF. Integration of human papillomavirus type 16 DNA into the human genome leads to increased stability of E6 and E7 mRNAs: implications for cervical carcinogenesis. Proc Natl Acad Sci U S A 1995;92:1654-8.

8. Werness BA, Levine AJ, Howley PM. Association of human papillomavirus types 16 and 18 E6 proteins with p53. Science 1990;248:76-9.

9. Scheffner M, Werness BA, Huibregtse JM, Levine AJ, Howley PM. The E6 oncoprotein encoded by human papillomavirus types 16 and 18 promotes the degradation of p53. Cell 1990; 63:1129-36.

10. Scheffner M, Huibregtse JM, Vierstra RD, Howley PM. The HPV-16 E6 and E6-AP complex functions as a ubiquitinprotein ligase in the ubiquitination of p53. Cell 1993;75:495505.

11. Dyson N, Howley PM, Munger K, Harlow E. The human papilloma virus-16 E7 oncoprotein is able to bind to the retinoblastoma gene product. Science 1989;243:934-7.

12. Boyer SN, Wazer DE, Band V. E7 protein of human papilloma virus-16 induces degradation of retinoblastoma protein through the ubiquitin-proteasome pathway. Cancer Res 1996;56:4620-4.

13. Hawley-Nelson P, Vousden KH, Hubbert NL, Lowy DR, Schiller JT. HPV16 E6 and E7 proteins cooperate to immortalize human foreskin keratinocytes. EMBO J 1989;8:390510.

14. Munger K, Phelps WC, Bubb V, Howley PM, Schlegel R. The E6 and E7 genes of the human papillomavirus type 16 together are necessary and sufficient for transformation of primary human keratinocytes. J Virol 1989;63:4417-21.

15. Ishiji T. Molecular mechanism of carcinogenesis by human papillomavirus-16. J Dermatol 2000;27:73-86.

16. Giarre M, Caldeira S, Malanchi I, Ciccolini F, Leao MJ, Tommasino M. Induction of $\mathrm{pRb}$ degradation by the human papillomavirus type $16 \mathrm{E} 7$ protein is essential to efficiently overcome p16INK4a-imposed G1 cell cycle arrest. J Virol 2001;75:4705-12.

17. Helt AM, Funk JO, Galloway DA. Inactivation of both the retinoblastoma tumor suppressor and p21 by the human papillomavirus type 16 E7 oncoprotein is necessary to in- 
hibit cell cycle arrest in human epithelial cells. J Virol 2002; 76:10559-68.

18. Sano T, Oyama T, Kashiwabara K, Fukuda T, Nakajima T. Immunohistochemical overexpression of p16 protein associated with intact retinoblastoma protein expression in cervical cancer and cervical intraepithelial neoplasia. Pathol Int 1998;48:580-5.

19. Sano T, Oyama T, Kashiwabara K, Fukuda T, Nakajima T. Expression status of p16 protein is associated with human papillomavirus oncogenic potential in cervical and genital lesions. Am J Pathol 1998;153:1741-8.

20. Keating JT, Cviko A, Riethdorf S, Riethdorf L, Quade BJ, Sun $\mathrm{D}$, et al. Ki-67, cyclin E, and $\mathrm{p} 16^{\mathrm{INK} 4}$ are complimentary surrogate biomarkers for human papilloma virus-related cervical neoplasia. Am J Surg Pathol 2001;25:884-91.

21. Milde-Langosch K, Riethdorf S, Kraus-Poppinghaus A, Riethdorf L, Loning T. Expression of cyclin-dependent kinase inhibitors p16 ${ }^{\mathrm{MTS} 1}, \mathrm{p} 21^{\mathrm{WAF} 1}$, and $\mathrm{p} 27^{\mathrm{KIP} 1}$ in HPV-positive and HPV-negative cervical adenocarcinomas. Virchows Arch 2001;439:55-61.

22. Klaes R, Friedrich T, Spitkovsky D, Ridder R, Rudy W, Petry $\mathrm{U}$, et al. Overexpression of $\mathrm{p} 16^{\mathrm{INK} 4 \mathrm{~A}}$ as a specific marker for dysplastic and neoplastic epithelial cells of the cervix uteri. Int J Cancer 2001;92:276-84.

23. Wiest T, Schwarz E, Enders C, Flechtenmacher C, Bosch FX. Involvement of intact HPV16 E6/E7 gene expression in head and neck cancers with unaltered p53 status and perturbed pRb cell cycle control. Oncogene 2002;21:1510-7.

24. Li Y, Nichols MA, Shay JW, Xiong Y. Transcriptional repression of the D-type cyclin-dependent kinase inhibitor p16 by the retinoblastoma susceptibility gene product $\mathrm{pRb}$. Cancer Res 1994;54:6078-82.

25. Khleif SN, DeGregori J, Yee CL, Otterson GA, Kaye FJ, Nevins JR, et al. Inhibition of cyclin D-CDK4/CDK6 activity is associated with an E2F-mediated induction of cyclin kinase inhibitor activity. Proc Natl Acad Sci U S A 1996;93:4350-4.

26. Sherr CJ. Cancer cell cycles. Science 1996;274:1672-7.

27. Frisch M, Glimelius B, van den Brule AJ, Wohlfahrt J, Meijer CJ, Walboomers JM, et al. Sexually transmitted infection as a cause of anal cancer. N Engl J Med 1997;337:1350-8.

28. Frisch M, Fenger C, van den Brule AJ, Sorensen P, Meijer CJ, Walboomers JM, et al. Variants of squamous cell carcinoma of the anal canal and perianal skin and their relation to human papillomaviruses. Cancer Res 1999;59:753-7.

29. Ryan DP, Compton CC, Mayer RJ. Carcinoma of the anal canal. N Engl J Med 2000;342:792-800.

30. Jakate SM, Saclarides TJ. Immunohistochemical detection of mutant p53 protein and human papillomavirus-related E6 protein in anal cancers. Dis Colon Rectum 1993;36:1026-9.

31. Ogunbiyi OA, Scholefield JH, Smith JH, Polacarz SV, Rogers K, Sharp F. Immunohistochemical analysis of p53 expression in anal squamous neoplasia. J Clin Pathol 1993; 46:507-12.

32. Tanum G, Holm R. Anal carcinoma: a clinical approach to p53 and RB gene proteins. Oncology 1996;53:369-73.

33. Indinnimeo M, Cicchini C, Stazi A, Giarnieri E, French D, Limiti MR, Ghini C, Vecchione A. Human papillomavirus infection and p53 nuclear overexpression in anal canal carcinoma. J Exp Clin Cancer Res 1999;18:47-52.

34. el Mofty K, Lu DW. Human papilloma virus (HPV) infection in squamous cell carcinoma of the head and neck in young patients [abstract]. Histopathology 2002;41(Suppl 1):26.

35. Kleter B, van Doorn LJ, ter Schegget J, Schrauwen L, van Krimpen K, Burger M, et al. Novel short-fragment PCR assay for highly sensitive broad-spectrum detection of anogenital human papillomaviruses. Am J Pathol 1998; 153:1731-9.

36. Kleter B, van Doorn LJ, Schrauwen L, Molijn A, Sastrowijoto $\mathrm{S}$, ter Schegget J, et al. Development and clinical evaluation of a highly sensitive PCR-reverse hybridization line probe assay for detection and identification of anogenital human papillomavirus. J Clin Microbiol 1999;37:2508-17.

37. Saiki RK, Scharf S, Faloona F, Mullis KB, Horn GT, Erlich HA, et al. Enzymatic amplification of $\beta$-globin genomic sequences and restriction site analysis for diagnosis of sickle cell anemia. Science 1985;230:1350-4.

38. Wang HL, Wang J, Xiao SY, Haydon R, Stoiber D, He TC, et al. Elevated protein expression of cyclin D1 and Fra-1 but decreased expression of c-Myc in human colorectal adenocarcinomas overexpressing $\beta$-catenin. Int J Cancer 2002;101:301-10.

39. Levine AJ. $p 53$, the cellular gatekeeper for growth and division. Cell 1997;88:323-31.

40. Crook T, Wrede D, Tidy J, Scholefield J, Crawford L, Vousden KH. Status of c-myc, p53 and retinoblastoma genes in human papillomavirus positive and negative squamous cell carcinomas of the anus. Oncogene 1991;6:1251-7.

41. Hall PA, Lane DP. p53 in tumour pathology: can we trust immunohistochemistry?-revisited! J Pathol 1994;172:1-4.

42. Clurman BE, Groudine M. The CDKN2A tumor-suppressor locus - a tale of two proteins. N Engl J Med 1998;338:910-2.

43. Hagmar B, Christensen JJ, Johansson B, Kalantari M, Ryd W, Skyldberg B, et al. Implications of human papillomavirus type for survival in cervical squamous cell carcinoma. Int J Gynecol Cancer 1995;5:341-5.

44. Lai HC, Sun CA, Yu MH, Chen HJ, Liu HS, Chu TY. Favorable clinical outcome of cervical cancers infected with human papilloma virus type 58 and related types. Int J Cancer 1999; 84:553-7.

45. Schwartz SM, Daling JR, Shera KA, Madeleine MM, McKnight B, Galloway DA, et al. Human papillomavirus and prognosis of invasive cervical cancer: a population-based study. J Clin Oncol 2001;19:1906-15.

46. Pilch H, Gunzel S, Schaffer U, Tanner B, Brockerhoff P, Maeurer M, et al. The presence of HPV DNA in cervical cancer: correlation with clinico-pathologic parameters and prognostic significance: 10 years experience at the Department of Obstetrics and Gynecology of the Mainz University. Int J Gynecol Cancer 2001;11:39-48.

47. Lo KW, Cheung TH, Chung TK, Wang VW, Poon JS, Li JC, et al. Clinical and prognostic significance of human papillomavirus in a Chinese population of cervical cancers. Gynecol Obstet Invest 2001;51:202-7.

48. Harima Y, Sawada S, Nagata K, Sougawa M, Ohnishi T. Human papilloma virus (HPV) DNA associated with prognosis of cervical cancer after radiotherapy. Int J Radiat Oncol Biol Phys 2002;52:1345-51.

49. Bezerra AL, Lopes A, Santiago GH, Ribeiro KC, Latorre MR, Villa LL. Human papillomavirus as a prognostic factor in carcinoma of the penis: analysis of 82 patients treated with amputation and bilateral lymphadenectomy. Cancer 2001; 91:2315-21.

50. Iwamasa T, Miyagi J, Tsuhako K, Kinjo T, Kamada Y, Hirayasu T, et al. Prognostic implication of human papillomavirus infection in squamous cell carcinoma of the lung. Pathol Res Pract 2000;196:209-18.

51. Schwartz SR, Yueh B, McDougall JK, Daling JR, Schwartz SM. Human papillomavirus infection and survival in oral squamous cell cancer: a population-based study. Otolaryngol Head Neck Surg 2001;125:1-9.

52. Sisk EA, Soltys SG, Zhu S, Fisher SG, Carey TE, Bradford CR. Human papillomavirus and p53 mutational status as prognostic factors in head and neck carcinoma. Head Neck 2002; 24:841-9.

53. Keating JT, Ince T, Crum CP. Surrogate biomarkers of HPV infection in cervical neoplasia screening and diagnosis. Adv Anat Pathol 2001;8:83-92. 